\title{
ОСОБЕННОСТИ ГЕОХИМИИ ЦИРКОНИЯ И ГАФНИЯ В ПРОЦЕССАХ МАНТИЙНОГО КАРБОНАТНОГО МЕТАСОМАТОЗА
}

\section{Когарко Л.Н.}

Институт геохимии и аналитической химии им. В.И. Вернадского РАH, Москва, kogarko@geokhi.ru

Карбонатитовые расплавы являются активными агентами мантийного метасоматоза $[1,2,3]$. Инфильтрация расплав-флюидов, обогащенных несовместимыми элементами приводит к возникновению обогащенных резервуаров-источников щелочно-карбонатитового магнматизма и связанных с ними месторождений стратегических металлов. Согласно экспериментальным данным в процессах частичного плавления мантийного субстрата в присутствии $\mathrm{CO}_{2}$ будут возникать расплавы доломитового состава, миграция которых вызывает возникновение метасоматических зон согласно реакциям

$$
\begin{aligned}
& 4 \mathrm{MgSiO}_{3}+\mathrm{CaM}^{\wedge}\left(\mathrm{CO}_{3}\right)_{2}=2 \mathrm{Mg}_{2} \mathrm{SiO}_{4+} 2 \mathrm{CO}_{2}, \\
& 3 \mathrm{CaMg}\left(\mathrm{CO}_{3}\right)_{2}+\mathrm{CaMgSi}_{2} \mathrm{O}_{6}=4 \mathrm{CaCO}_{3}+2 \mathrm{Mg}_{2} \mathrm{SiO}_{4}+\mathrm{CO}_{2}[1,4]
\end{aligned}
$$

Несмотря на очень ограниченный объем информации по геохимии элементов-аналогов в мантийном субстрате, разделение Zr и Нf в процессах карбонатного метасоматоза отмечалось в глубинных нодулях северной Танзании [3], острова Шпицберген [2] и других регионов. Эти исследования показали, что в карбонатизированных мантийных нодулях отношение $\mathrm{Zr} / \mathrm{Hf}$ значительно возрастает и достигает иногда величин, превышающих 100 [3].

Наши исследования карбонатного метасоматоза в глубинных мантийных ксенолитах [1] ряда регионов также показали заметное разделение $\mathrm{Zr}$ и $\mathrm{Hf}$.

Особенно ярко эта закономерность проявилась в метасматизированных мантийных ксенолитах Восточной Антарктиды, оазис Джетти, приуроченный к палеозойской рифтовой системе Бивер. Рифтовая зона протяженностью 400км простирается в северном,северо-западном направлении. Возраст вмещающих оливиновых меланефелинитов, определенный K-Ar методом - нижний мел. Глубинные ксенолиты Восточной Антарктиды занимают 20-25 \% пространства и имеют различные размеры от нескольких см до 0.7 м. Ассоциация мантийных ксенолитов отражает протяженный разрез верхней мантии и коры Восточной Антарктиды и включает гранат-содержащие и шпинелевые лецолиты, габсбургиты, дуниты и обломки корового материала. Большинство ксенолитов обладают протогранулярной структурой согласно классификации Мерсье и Николя [5]. Главными породообразующими минералами мантийных ксенолитов являются оливин, клинопироксен, ортопироксен, шпи-

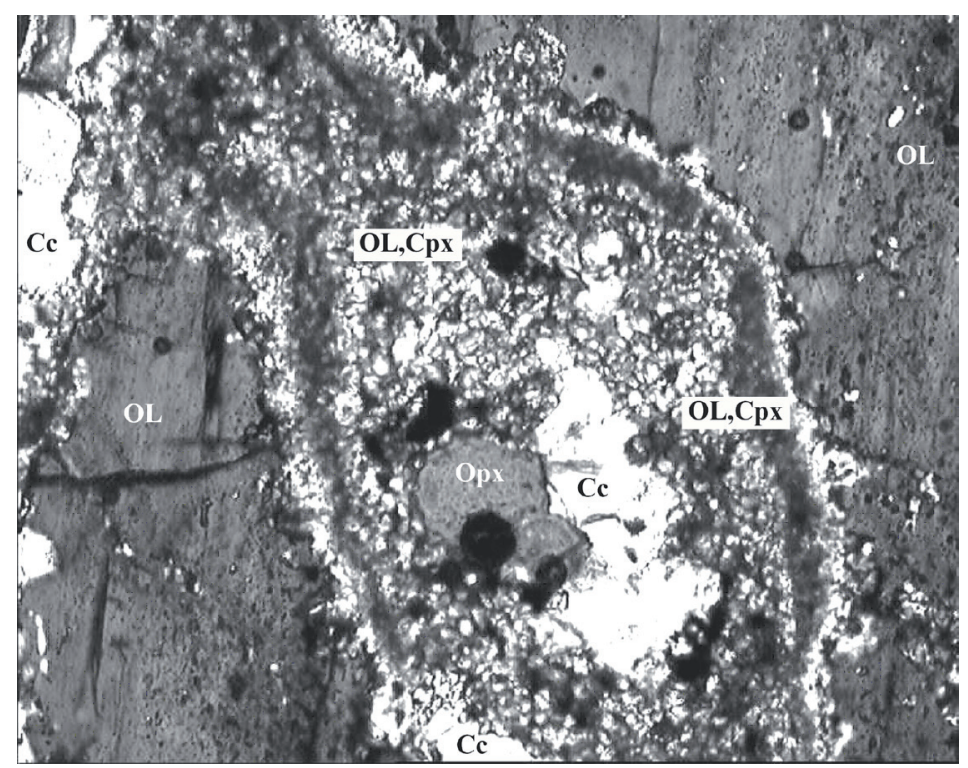

Рис. 1. Реакционная зона в метасоматизированной мантии.

$\mathrm{OL}$ - оливин, Cc - карбонат, Opx - ортопироксен, Cpx, OL - реакционная зона. 
нель, гранат. Во многих ксенолитах встречаются зоны неправильной формы, жилообразные выделения карбонатного материала, представленного кальцитом, доломитом и магнезитом. Эти участки по своим структурным особенностям имеют более поздний характер, прожилки карбонатного материала секут главные породообразующие минералы и образуют реакционные зоны, которые главным образом развиты и замещают ортопироксены (рис. 1). В метасоматических участках мы обнаружили ряд акцессорных минералов-апатит, слюды и впервые в мантийном субстрате найден генримейерит [4]. $\left(\mathrm{Ba}_{0.97} \mathrm{Ca}_{0.03} \mathrm{~K}_{0.03} \mathrm{Na}_{0.11}\right) \sum_{1.14}\left(\mathrm{Fe}_{0.92} \mathrm{Mg}_{0.17} \mathrm{Al}_{0.02}\right) \sum_{1.11}\left(\mathrm{Ti}_{6.66} \mathrm{Si}_{0.25}\right) \sum_{6.91} \mathrm{O}_{16}$ который ранее был обнаружен в карбонатитах Ковдорского комплекса (Кольский полуостров) [6]. Используя методы нейтронно активационного и рентгено-флюоресцентного анализа, а также лазерной абляции MC-ICP-MS, мы определили составы ряда мантийных ксенолитов и распределение в них и некоторых минералах циркония и гафния (табл. 1). Все исследованные нодули претерпели процессы частичного плавления так как в них концентрации Са и $\mathrm{Al}$ ниже содержаний этих элементов в примитивной мантии $\mathrm{CaO}-3.65$ масс. \%, $\mathrm{Al}_{2} \mathrm{O}_{3}-4.49$ масс. \% [7]. В процессах частичного плавления мантии в расплав будут переходить в первую очередь несовместимые элементы, к которым принадлежат цирконий и гафний, в которых величины коэффициентов распреденления в равновесиях расплав- минералы мантии очень низки-тысячные доли. При степени плавления мантийного субстрата $1 \%$ несовместимые элементы (Zr Hf) практически полностью переходят в равновесный расплав [8]. Валовые коэффициенты распределения кальция и алюминия в процессах частичного плавления мантии значительно выше-несколько десятых \%. Отсюда можно сделать вывод, что в исследованных мантийных ксенолитах (табл. 1) весь Zr и Нf были привнесены в результате метасоматических процессов во всяком случае в нодулях $\mathrm{N} 1,5,6$, в которых содержания кальция и алюминия заметно снижены и материал которых был подвергнут частичному плавлению на несколько процентов. Таким образом заметное фракционирование циркония и гафния в исследованных мантийных ксенолитах является результатом метасоматического привноса в уже проплавленный мантийный субстрат. С другой стороны, во всех без исключения метасоматизированных ксенолитах присутствует стекло в основном фонолитового и кварцсиенитового состава. Это значит, что история исследованного мантийного материала весьма сложная и по всей вероятности и карбонатизированный мантийный материал в свою очередь плавился в результате значительного понижения температуры солидуса в ходе метасоматического привноса летучих компонентов. Нами в нодулях о-ва Монтана-Клара (Канарский архипелаг) [1] исследованы процессы частичного плавления карбонатизированного мантийного субстрата в ходе которых возникают три несмешивающихся жидкости-силикатная сиенитового состава, карбонатная, близкая по составу к кальцитовым карбонатитам и сульфидная.

Таблица 1. Распределение $\mathrm{Zr}$ и Hf в карбонатизированных мантийных ксенолитах и метасоматических клинопироксенах.

\begin{tabular}{|c|c|c|c|c|c|c|c|}
\hline \multicolumn{3}{|c|}{$\begin{array}{c}\text { Карбонатизированные } \\
\text { мантийные нодули }\end{array}$} & \multicolumn{3}{c|}{ Клинопироксены } \\
\hline № п/п & $\mathrm{Zr}$ & Hf & $\mathrm{Zr} / \mathrm{Hf}$ & № п/п & $\mathrm{Zr}$ & Hf & Zr/Hf \\
\hline 1 & 20.0 & 0.13 & 153 & 1 & 26.7 & 1.07 & Центр 25 \\
\hline 2 & 10.0 & 0.04 & 227 & 1 & 26.4 & 0.4 & Край 71 \\
\hline 3 & 12.0 & 0.15 & 80 & 2 & 678 & 8.43 & 80 \\
\hline 4 & 15.0 & 0.17 & 88 & 3 & 367 & 8.00 & 46 \\
\hline 5 & 31.0 & 0.21 & 148 & 4 & 627 & 9.53 & 66 \\
\hline среднее & 17.6 & 0.14 & 125 & среднее & 345.02 & 5.49 & 57.6 \\
\hline
\end{tabular}

Одним из главных геохимических следствий процесса карбонатизации мантийного материала является реакция замещения ортопироксена клинопироксеном, в результате которого развивается верлитизация глубинного субстрата. По нашему мнению, значительное расширение поля кристаллизации клинопироксена, обладающего более высоким коэффициентом распределения Hf по сравнению с Zr, приводит к формированию карбонатно-силикатных расплавов, обладающих более вы- 
сокими отношениями $\mathrm{Zr} / \mathrm{Hf}$, что объясняет заметное отклонение этого отношения в большую сторону от хондритового во многих карбонатитах $[9,10,11]$. Наши исследования показали довольно высокие отношения $\mathrm{Zr} / \mathrm{Hf}$ в карбонатитах Полярной Сибири, Украины и О-вов Зеленого мыса (табл. 2).

Таблица 2. Распределение $\mathrm{Zr}$ и Нf в карбонатитах Черниговского массива (1) и островов Зеленого Мыса (2), Гулинского массива (3).

\begin{tabular}{|c|c|c|c|c|c|c|c|}
\hline \multicolumn{4}{|c|}{ Кальцитовые карбонатиты (1) } & \multicolumn{4}{|c|}{ Доломитовые карбонатиты (1) } \\
\hline № ח/п & $\mathrm{Zr}$ & Hf & $\mathrm{Zr} / \mathrm{Hf}$ & № П/п & $\mathrm{Zr}$ & Hf & $\mathrm{Zr} / \mathrm{Hf}$ \\
\hline 1 & 588 & 6.9 & 85.1 & 1 & 93.2 & 2.1 & 44.2 \\
\hline 2 & 55.1 & 1.5 & 36.2 & 2 & 55.1 & 1.4 & 40.5 \\
\hline 3 & 69.5 & 1.8 & 37.7 & 3 & 36 & 0.9 & 39.7 \\
\hline 4 & 44.9 & 1.7 & 25.9 & 4 & 563 & 13.9 & 40.5 \\
\hline 5 & 630 & 10.8 & 58.6 & 5 & 112 & 2.5 & 44.9 \\
\hline 6 & 396 & 4.8 & 82.4 & 6 & 7.1 & 0.3 & 27.4 \\
\hline 7 & 301 & 3 & 100 & 7 & 73.1 & 0.9 & 80.1 \\
\hline 8 & 32.3 & 1.1 & 28.2 & Среднее & 134 & 3.1 & 45.3 \\
\hline 9 & 378 & 6.9 & 54.9 & \multicolumn{4}{|c|}{ Карбонатиты (3) } \\
\hline Среднее & 277 & 4.3 & 56.6 & № ח/п & $\mathrm{Zr}$ & Hf & $\mathrm{Zr} / \mathrm{Hf}$ \\
\hline \multicolumn{4}{|c|}{ Карбонатиты (2) } & 1 & 219 & 7.2 & 30.7 \\
\hline № П/П & $\mathrm{Zr}$ & Hf & $\mathrm{Zr} / \mathrm{Hf}$ & 2 & 342 & 8.3 & 41.1 \\
\hline 1 & 475 & 9.9 & 47.8 & 3 & 66 & 2 & 33.9 \\
\hline 2 & 56 & 0.9 & 58.9 & 4 & 12383 & 411 & 30.1 \\
\hline 3 & 123 & 0.9 & 137 & 5 & 1945 & 62 & 31.4 \\
\hline 4 & 304 & 7.8 & 38.8 & 6 & 63.1 & 1.3 & 48.5 \\
\hline 5 & 9,1 & 0.1 & 73.3 & 7 & 1891 & 2 & 93.8 \\
\hline 6 & 350 & 3 & 115 & 8 & 321 & 3.3 & 98.7 \\
\hline 7 & 125 & 1.6 & 80.2 & 9 & 164 & 3 & 54.7 \\
\hline 8 & 173 & 4.2 & 41.5 & 10 & 210 & 2.9 & 73.3 \\
\hline 9 & 66,8 & 0.9 & 75.3 & 11 & 179 & 3 & 59.7 \\
\hline \multirow{8}{*}{ среонее } & 187 & 3.3 & 74.2 & 12 & 15 & 0.3 & 49.8 \\
\hline & & & & 13 & 55 & 0.4 & 147 \\
\hline & & & & 14 & 35 & 1.5 & 23 \\
\hline & & & & 15 & 47 & 0.4 & 107.2 \\
\hline & & & & 16 & 106 & 1.7 & 62.4 \\
\hline & & & & 17 & 2.6 & 0.1 & 44 \\
\hline & & & & 18 & 13.5 & 0.2 & 86.8 \\
\hline & & & & Среднее & 1003 & 28 & 62 \\
\hline
\end{tabular}

Продвижение в верхние структурные этажи подобных карбонатных расплавов будет вызывать метасоматические реакции и образование карбонатизированных зон с повышенным отношением $\mathrm{Zr} / \mathrm{Hf}$, что и наблюдается в глубинных ксенолитах Восточной Антарктиды.

Содержание ортопироксена в мантийном субстрате составляет более $20 \%$ так что замещение этого минерала клинопироксеном, фракционирующим Zr и Hf, несомненно, внесет существенный вклад в увеличение отношения $\mathrm{Zr} / \mathrm{Hf}$ в выплавляющиеся карбонатитовые и карбонатно-силикатные расплавы. Предложенная нами модель фракционирования циркония и гафния в процессах карбонатного мантийного метасоматоза подтверждается характером распределения этих элементов в пироксенах карбонатизированных нодулей Восточной Антарктиды. Клинопироксены первой генера- 
ции обладают более низкими отношениями $\mathrm{Zr} / \mathrm{Hf}$ по сравнению с пироксенами второй генерации, которые возникают в процессах метасоматического замещения первичного ортопироксена (табл. 1). Интересно, что в некоторых метасоматических зонах присутствуют зональные пироксены, представляющие собой замещение первичных фаз продуктами реакции. От центра пироксенов к краевым зонам отмечается рост отношений $\mathrm{Zr} / \mathrm{Hf}$ (табл. 1).

Сочетание мантийного метасоматоза в условиях повышенного режима летучих компонентов, в основном углекислоты, вариаций параметров частичного плавления мантийного субстрата, несомненно, является причиной глубокой геохимической дифференциации глубинных зон магмаобразования и приводит к фракционированию редких элементов и возникновению обогащенных ими резервуаров-источников карбонатитового магматизма и связанных с ним месторождений стратегических металлов. Этот процесс приобретает крупномасштабный характер в зонах магмаобразования крупных магматических провинций, являющихся результатом ассоциации с мантийными плюмами.

\section{Литература}

1. Kogarko L.N., Henderson C.M.B., Pacheco H. Primary Ca-rich carbonatite magma and carbonate-silicatesulphide liquid immiscibility in the upper mantle // Contrib. Mineral. Petrol. 1995. V. 121. P. 267-274.

2. Ionov D.A., Dupuy C., O’Reilly S.Y., Kopylova M.G., Genshaft Y.S. Carbonated peridotite xenoliths from Spitsbergen: implications for trace element signature of mantle carbonate metasomatism // Earth Planet. Sci. Lett. 1993. V. 119. P. 282-297.

3. Rudnick R.L., McDonough W.F., Chappell B.W. Carbonatite metasomatism in the northern Tanzanian mantle: petrographic and geochemical characteristics // Earth Plant. Sci. Lett. 1992. V. 114. P. 463-475.

4. Kogarko L. N., Kurat G., and Ntaflos T. Henrymeyerite in the metasomatized upper mantle of eastern Antarctica // The Canadian Mineralogist 2007. V. 45 № 3. P. 497-501.

5. Mercier S.C.C \& Nicolas A. Textures and fabrics of upper mantle peridotites as illustrated by basalt xenoliths // J. Petrol. 1975. V. 16. P. 454-487.

6. Mitchell R.H., Yakovenchuk V.N., Chakhmouradian A.R., Burns P.C. \&Pakhomovsky Y.A. Henrymeyerite, a new hollandite-type Ba-Fe titanite from the Kovdor complex, Russia // Can. Mineral. 2000. V. 38. P. 617-626.

7. Palme H., O'Neill H.St.C. Cosmochemical estimates of mantle composition // Treatise on geochemistry. 2003. V. 2. P. 1-38.

8. Girnis A.V., Bulatov V.K., Brey G.P., Gerdes A., Höfer H.E. Trace element partitioning between mantle minerals and silico-carbonate melts at $6-12 \mathrm{GPa}$ and applications to mantle metasomatism and kimberlite genesis. Lithos, 2013. V. 160-161 P. 183-200.

9. Hoernle K., Tilton G., Le Bas M. J., Duggen S. \& Garbe-Schoenberg D. Geochemistry of oceanic carbonatites compared with continental carbonatites: mantle recycling of oceanic crustal carbonate // Contrib Mineral Petrol 2002. V. 142. P. 520-542.

10. Chakhmouradian A.R. High-field-strength elements in carbonatitic rocks: geochemistry, crystal chemistry and significance for constraining the sources of carbonatites // Chemical Geology. 2006. V. 235. P. 138-160.

11. Dupuy C., Liotard J.M. \& Dostal J. Zr/Hf fractionation in intraplate basaltic rocks: Carbonate metasomatism in the mantle source // Geochim Cosmochim Acta. 1992. V. 56. P. 2417-2423. 